\title{
PML/RARA Single Fusion Probe
}

National Cancer Institute

\section{Source}

National Cancer Institute. PML/RARA Single Fusion Probe. NCI Thesaurus. Code C120387.

A set of two DNA probes designed for use in FISH; one hybridizes to either the 15q22 region containing the PML gene or the 17q21.1 region containing the RARA gene. This probe set detects the PML/RARA fusion gene. 